Helgoländer wiss. Meeresunters. 20, 304-317 (1970)

\title{
Cultivation experiments on North Sea ctenophores
}

\author{
W. GREVE \\ Biologische Anstalt Helgoland (Meeresstation); Helgoland, Germany (FRG)
}

KURZFASSUNG: Kulturversuche an Nordsee-Ctenophoren. Die Ctenophoren gehören zu den Holoplanktern, die im neritischen Bereich der Nordsee eine wichtige Rolle in der Nahrungskette spielen. Die Empfindlichkeit dieser Organismengruppe erschwert experimentelle Untersuchungen. Mit neuen Methoden und Geräten, der „Doppelküvette“ und dem „Phytoplanktonkreisel", die aus dem "Planktonkreisel“ (GREve 1968) entwickelt wurden, gelang die langfristige Hälterung der 4 Ctenophorenarten, die in der Deutschen Bucht vorkommen: Pleurobracbia pileus Fabr., Bolinopsis infundibulum MüLler, Beroe cucumis FABR. und Beroe gracilis KünNE. Die Kulturversuche lassen Aussagen über Ernährung, einige Verhaltensbesonderheiten, Entwicklung und Wachstumsgeschwindigkeit dieser 4 Arten zu. Die teilweise an nur geringen Individuenzahlen gewonnenen Ergebnisse ergänzen die wenigen vorhandenen Daten über die Ökologie der hiesigen Ctenophoren, die sich durch besondere interspezifische Beziehungen auszeichnen; so frißt Beroe gracilis nur Pleurobrachia pileus und Beroe cucumis fast nur Bolinopsis infundibulum.

\section{INTRODUCTION}

Of all holoplanktonic animals, ctenophores are among the greatest enemies of copepods and meroplanktonic larvae in the North Sea, especially in the neritic ecosystem (see Fraser 1962, Bishop 1969). Therefore the role of these populations must be carefully considered in local food web studies.

During recent years several attempts have been made with tank experiments and rearing devices, to obtain further information on the ecology of these holoplanktonic organisms and the order of magnitude of their influence on marine food chains (Bishop 1968, 1969, Petipa et al. 1968). These investigations are made considerably more difficult by the lack of adequate rearing devices, due to the delicacy of most members of this phylum. Wenzel (1958) even says, that their susceptibility to mechanical damage prevents them from being kept in glass containers at all. This is true for most common devices (HAUENSCHILD 1968).

\section{METHODS}

Injuries - caused by equipment, required for air and food supply or for the creation of water movement, necessary to keep the passively drifting plankton forms from settling on the bottom - may be prevented by the use of the planktonkreisel (GREVE 1968), illustrated in Figure 1. 
The specific characteristics of the planktonkreisel are the use of air in a separate arrangement for establishing water-movement (air bubble water pump), the rotation of the culture medium and the inside sand filter with a decomposing infauna. The horizontal rotation of vertically orientated drifters requires containers extensive in

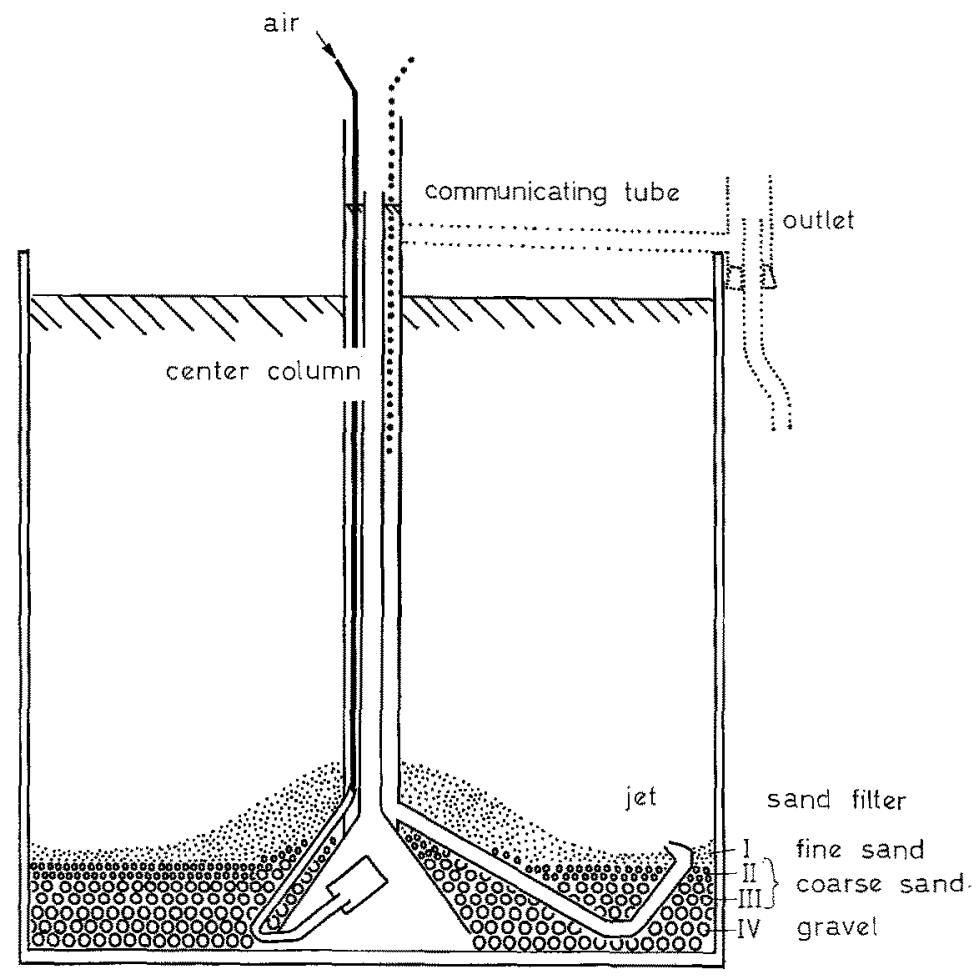

Fig. 1: Planktonkreisel. In the round jar, water rotation is caused by the air bubble water pump, which pumps the water from the botrom funnel to a bigher level in the center column. (After GREVE 1968, modified)

height and diameter. In such planktonkreisels it is difficult to control the test individuals as Pleurobrachia pileus for instance has long tentacles and is very sensitive to changes in temperature and salinity, and to vibration. Any manipulation causes disturbances in the behaviour pattern or even damages the tentacles. Hence size and feeding rate of $P$. pileus in the planktonkreisel can only be estimated.

The "double kuvette" (Fig. 2) uses a vertical rotation instead of the horizontal rotation inside the planktonkreisel. This permits to restrict the depth of the water body, to install the water transport system on the outside of the culture vessel and hence a better visual control of the organisms cultured. The double kuvette ( $40 \mathrm{X}$ $50 \times 10 \mathrm{~cm}$ ) consists of 2 chambers combined in the region of the gravel portion of the sand filter. Consequently the water mixes in the gravel and in the collection tube before returning to the chambers via jets (one in each chamber). The properties of the water itself thus remain identical in both chambers. The performance of the experi. 
mentals and the controls is continuously recorded photographically (Fig. 3). From the negatives the dimensions of the ctenophores cultivated and the number of food

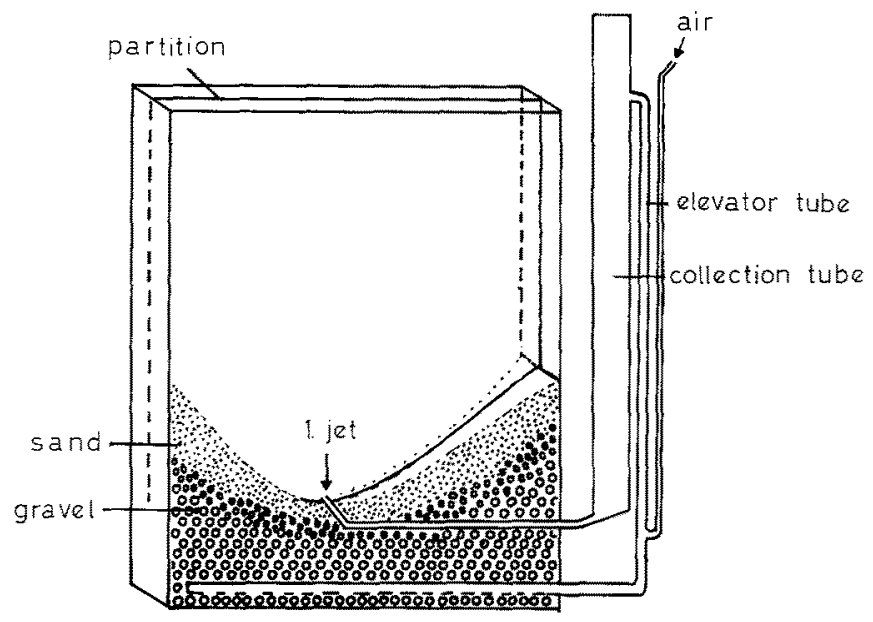

Fig. 2: Double kuvette. The partition divides the container in the upper part but allows the water to mix on its way through the substrate. The jets direct the vertical water rotation in each chamber. Two flash bulbs over the surface allow to take photographs

organisms present may be determined. The numbers of copepods counted in an experiment, in which 10 Pleurobracbia pileus were fed with copepods (Acartia longi-

\section{Table 1}

Determination of feeding rate of Pleurobrachia pileus in a double kuvette. Decrease in number of copepods due to mortality and additional decrease due to grazing. The feeding rate therefrom calculated is expressed in numbers of copepods consumed per individual ctenophore ( $=G_{1}$, see equation 1$)$. The last table column lists pharynx contents counted at comparable time intervals (dig. = digested organisms)

\begin{tabular}{|c|c|c|c|c|c|}
\hline \multirow{2}{*}{ Time } & \multicolumn{2}{|c|}{$\begin{array}{c}\text { Number of copepods per } \\
\text { chamber }\end{array}$} & \multirow{2}{*}{$\mathrm{G}_{1}$} & \multicolumn{2}{|c|}{$\begin{array}{l}\text { Number of copepods per } \\
\text { pharynx }\end{array}$} \\
\hline & $\begin{array}{c}\text { Experimentals } \\
\text { (10 Pleuro- } \\
\text { brachia } \\
\text { pileus) }\end{array}$ & $\begin{array}{l}\text { Controls } \\
\text { (without } \\
\text { Pleurobrachia } \\
\text { pileus) }\end{array}$ & & $\begin{array}{l}\text { calculated } \\
\text { from } \\
G_{1} \text { values }\end{array}$ & $\begin{array}{l}\text { counted } \\
\text { after } \\
\text { fixation }\end{array}$ \\
\hline 16.00 & 1530 & 1353 & - & - & - \\
\hline 16.10 & 1260 & 1340 & 27.0 & 27.0 & 94 \\
\hline 16.30 & 1100 & 1180 & 27.9 & 54.9 & 105 \\
\hline 17.00 & 880 & 1100 & 12.7 & 67.6 & $54+$ dig. \\
\hline 18.00 & 666 & 1080 & 21.4 & 89.0 & $84+$ dig. \\
\hline 20.00 & 406 & 1035 & 17.7 & 116.7 & - \\
\hline 0.00 & 40 & 1066 & 36.6 & 153.3 & - \\
\hline 8.30 & 12 & 953 & 2.1 & 155.4 & - \\
\hline 16.00 & 10 & 846 & - & - & - \\
\hline \multicolumn{5}{|c|}{$\mathrm{G}_{1}=\frac{\left(E_{1}-E_{2}\right)-\left(100-C_{2} \cdot 100: C_{1}\right) \cdot E_{1}: 100}{N}$} & (1) \\
\hline
\end{tabular}


cornis, Pseudocalanus elongatus and a few Calanus belgolandicus) to study their feeding rate are given in Table 1 . From the number of copepods counted in experimentals $(E)$ and controls $(C)$ average feeding rates per unit time $\left(G_{1}\right)$ are calculated
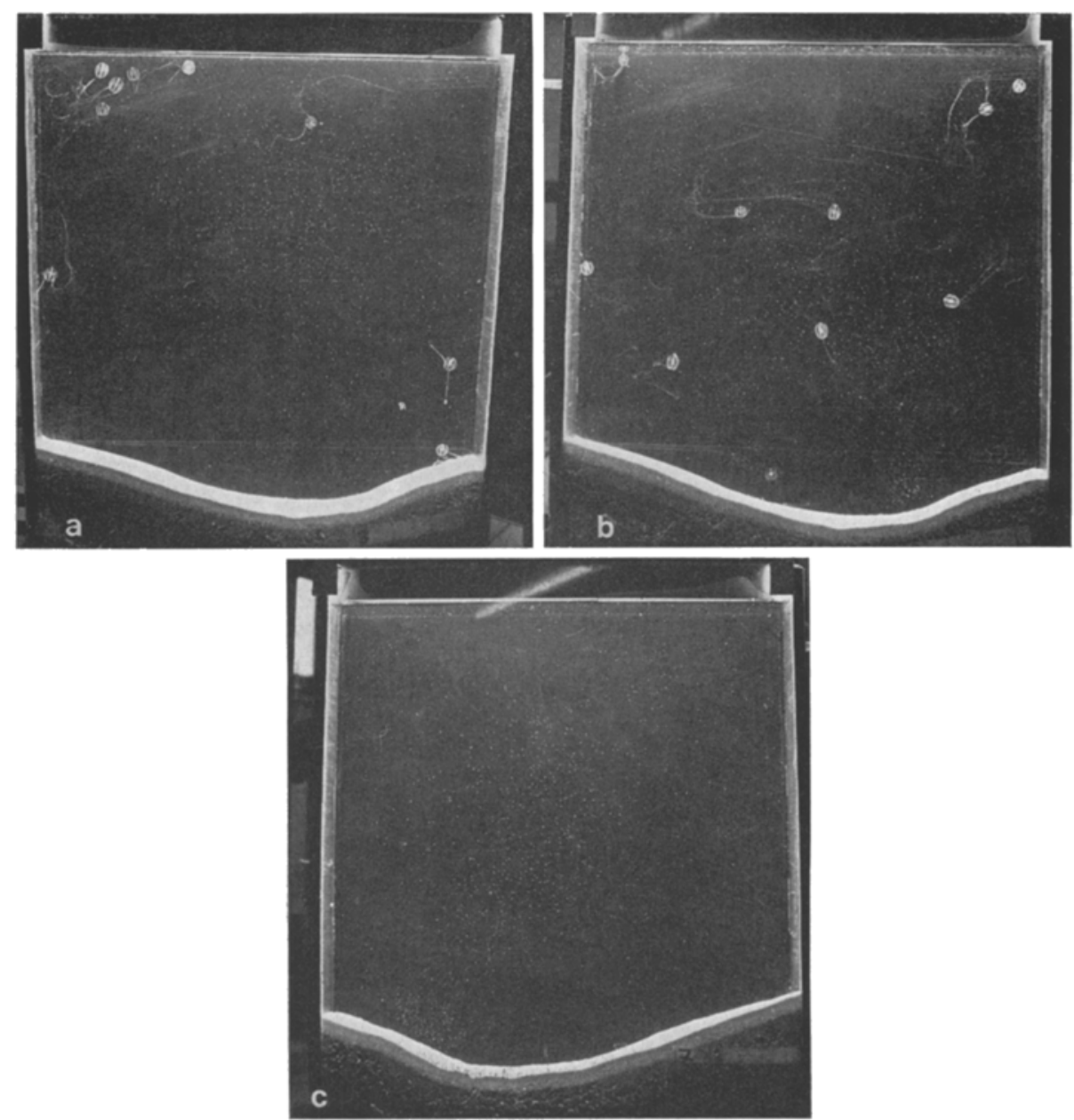

Fig. 3: Double kuvette during feeding experiment; $a$ beginning of experiment; copepods have been added; $b$ h later. a experimentals with 10 Pleurobrachia pileus; $c$ controls without $P$. pileus. The individual copepods are clearly visible; photographs at a $1: 1$ scale allow to determine changes in copepod numbers

employing the equation given below the table. Average cumulative numbers of copepods calculated from the $G_{1}$ values ( 5 th column) are compared to the number of copepods per pharynx determined after fixation of $P$. pileus of the same group. Subsequently, specimens which obviously had caught copepods were fixed in formalin and examined. These specimens contained in their pharynx a much higher number of cope- 
pods than revealed in average values. However, after $1 \mathrm{~h}$, comparable copepod numbers are obtained by calculations and counting.

Wild plankton caught near Helgoland usually contains considerable amounts of seston. In the planktonkreisel, seston is collected and decomposed by micro organisms in the sand filter. In view of the ecological importance of large amounts of seston it is desirable to devise experimental conditions under which the seston remains suspended in the water column, and to examine the effects of seston on planktonic organisms.

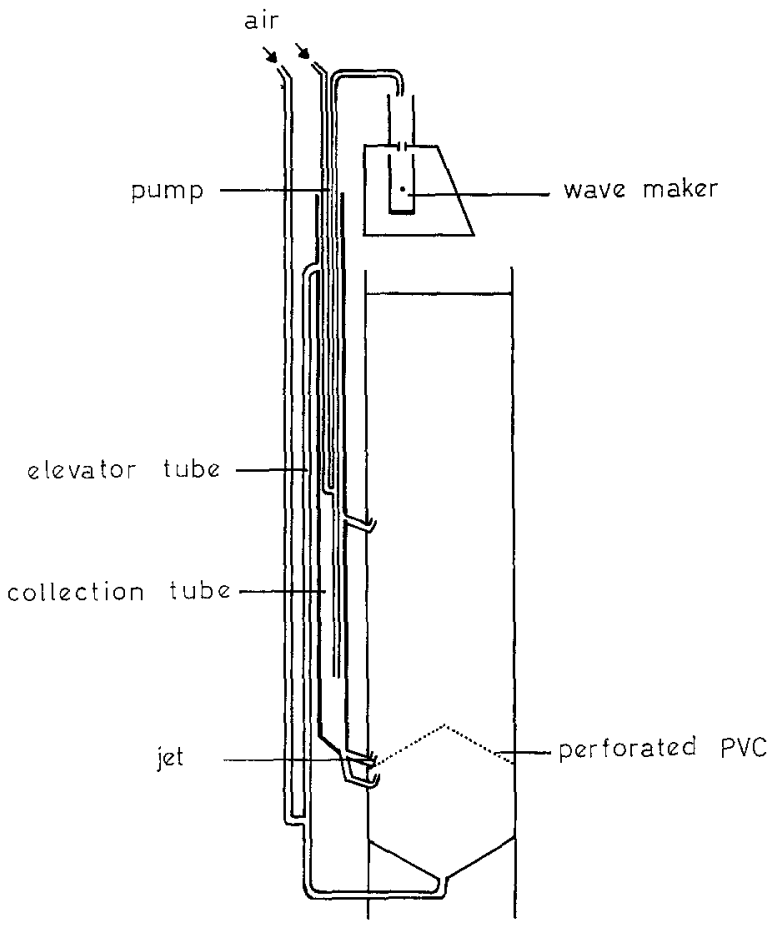

Fig. 4: Phytoplanktonkreisel. The sandfilter, used in the other devices, is replaced by a cone of perforated polyvinylchloride. The wave maker is a tiltable beaker with a lead-filled bottom

The "phytoplanktonkreisel" (Fig. 4) allows to conduct such experiments. Instead of the sand filter, the phytoplanktonkreisel contains a cone of perforated polyvinylchloride (PVC) through which seston particles sink towards the funnel-shaped bottom. The shape of this bottom and the water movement prevent the seston particles from sedimentation: they sink to the deepest point from where they are carried back by currents into the water column. Most zooplankton forms do not sink through the PVC cone which, therefore, protects most specimens from contacting air bubbles on their way to the collection tube.

In order to simulate surface wave action, the phytoplanktonkreisel can be equipped with an auxiliary device, a "wave maker". The wave maker is, in essence, a beaker mounted above the water surface of the phytoplanktonkreisel. An air bubble water 
pump fills the beaker with water from the collection tube. The beaker tilts when the weight of the water received exceeds the weight of its stabilizing lead-filled bottom. Hence, the tilting intervals can be regulated by the speed of water flow.

A very simple device which has been used successfully in our laboratory for cultivating ctenophores, and should be mentioned here, consists of a large glass cylinder containing about 101 of sea water, positioned at an inclination angle of $15^{\circ}$ to $25^{\circ}$. Water rotation is induced by an airation glass tube ending near the cylinder wall close to but not at the deepest point of the container. This device was used especially for maintaining very young ctenophores.

\section{RESULTS}

The 4 species investigated, Pleurobrachia pileus, Bolinopsis infundibulum, Beroe cucumis, and Beroe gracilis could be maintained in the given culture devices for at least 35 days. In the following paragraphs the length of the cultivation period, the devices used, the nutrition, specific behavioral aspects, development and growth rate

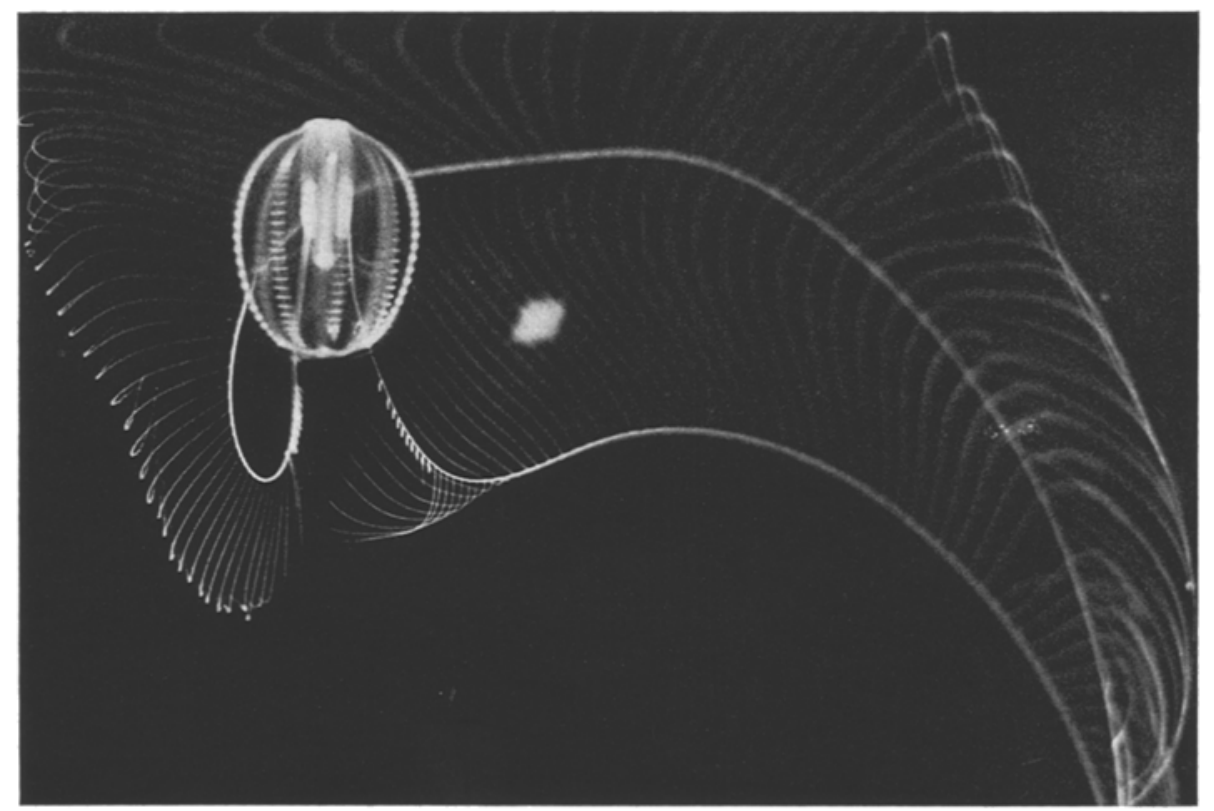

Fig. 5: Pleurobracbia pileus. Specimen, $12 \mathrm{~mm}$ in diameter, with its tentacles and catching threads stretched out

under laboratory conditions are reported for each species. It must be said, that even those results seemed worthwhile reporting, which are based on casual, short time experiments, as our knowledge of North Sea ctenophores is based almost exclusively on fixed plankton samples. 
Pleurobracbia pileus (Fig. 5) is by far the commonest species in the German Bight. The ctenophore could be reared from egg to adulthood and maintained for a maximum of 250 days. This was possible in the double kuvette and in the planktonkreisel. Most young $P$. pileus died at a size ranging from 0.1 to $2.0 \mathrm{~mm}$ diameter. Mortality was lowest in tilted, glass cylinders.

The food of young Pleurobracbia pileus consists mainly of unprotected larvae of benthic polychaets or molluscs. In the laboratory copepods, the main food source of adult individuals exert a detremental influence on young specimens. In terms of

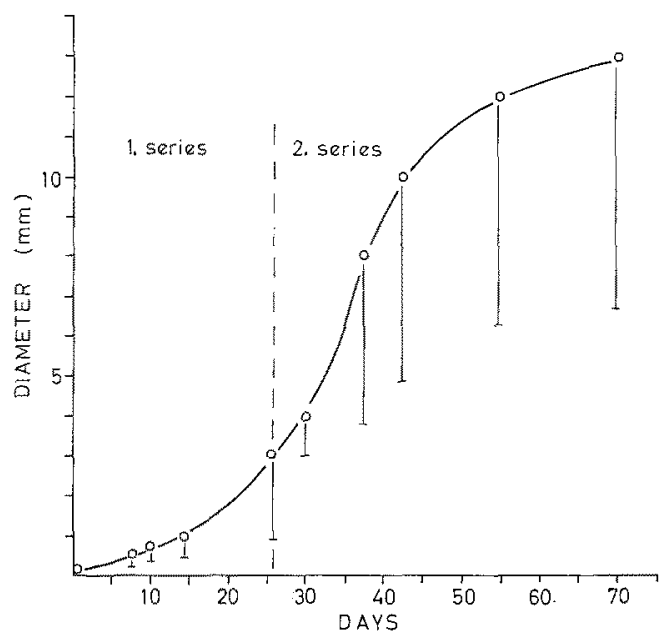

Fig. 6: Pleurobracbia pileus. Combined growth curve of the two fastest growing specimens from two experiments; the size ranges of the other individuals are indicated in vertical lines

size, young $P$. pileus are not larger than some food organisms of the copepods, e.g. diatoms such as Coscinodiscus concinnus. Larger $P$. pileus feed on a great variety of actively swimming organisms. Prey is limited by the catching apparatus of the ctenophore.

Pleurobrachia pileus is a passive drifter when searching for prey. The 2 tentacles, up to $50 \mathrm{~cm}$ long and their $4 \mathrm{~cm}$ long catching threads with colloblasts, form a "spider's net" amidst the seston particles. This could be observed in the phytoplanktonkreisel. Animals which feed on these particles (diatoms and detritus) swim into the net, when filtrating the water body. The method used by $P$. pileus enables it to select a few copepods from a majority of other seston particles. Young $P$. pileus behave in a similar way. Therefore, they cannot catch their prey in too small a container.

The development of Pleurobrachia pileus from fertilisation to hatching and from a diameter of $2 \mathrm{~mm}$ to adulthood can be studied under controlled conditions. A high population density of adult $P$. pileus activates the gonads of well-fed specimens. Under favorable conditions, eggs may be released in less than 2 days; they complete embryonic development within about $24 \mathrm{~h}$ at $15^{\circ} \mathrm{C}$. After hatching, the young 
ctenophores must be transferred to bigger containers. In these, less than $1 \%$ survived in all experiments. Maximum possible growth rates (Fig. 6) are attained by a small

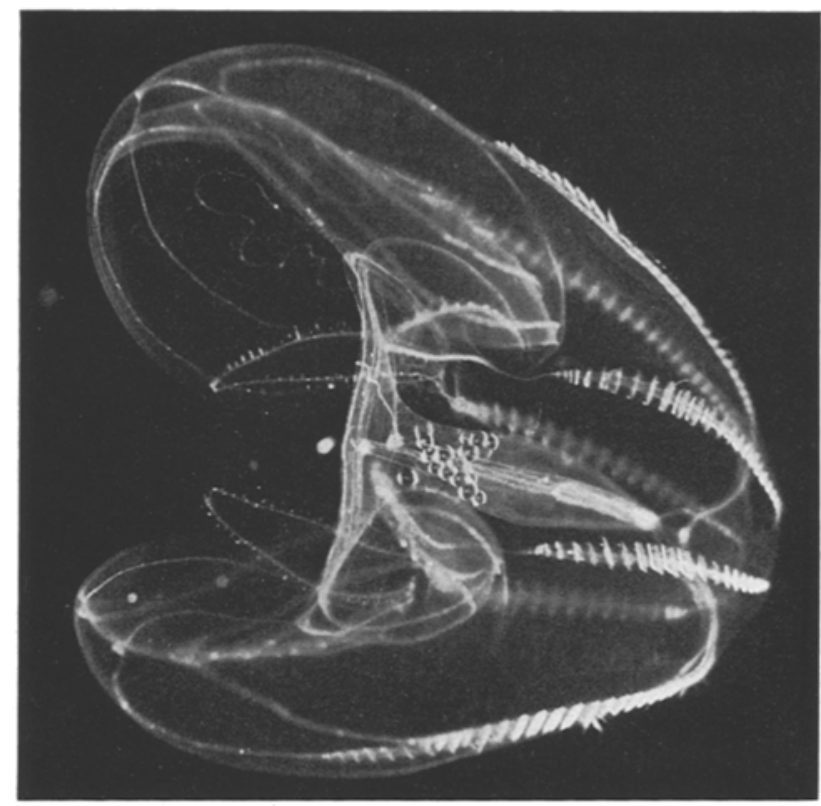

Fig. 7: Bolinopsis infundibulum (25 mm long). The pharynx contains eggs of Pleurobrachia pileus

number of individuals only. After reaching a size of $2-3 \mathrm{~mm}$ in diameter, mortality decreases and most $P$. pileus continue to grow on until they begin to reproduce. Minimum size for reproduction was $5.5 \mathrm{~mm}$ diameter, most individuals begin to repro-

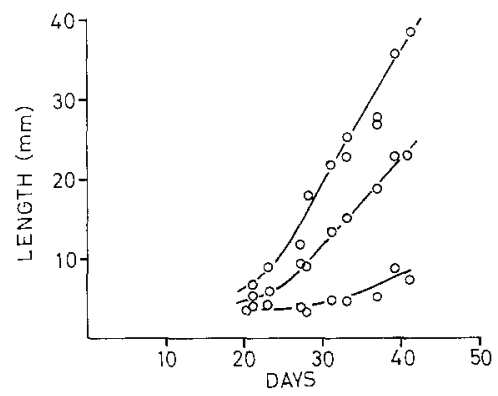

Fig. 8: Bolinopsis infundibulum. Average growth rate: middle curve; upper curve indicates maximum, lower curve minimum growth rates $\left(16^{\circ} \mathrm{C}\right)$

duce at a diameter of about $11 \mathrm{~mm}$. In most experiments growth rates of the single specimens varied considerably. Maximum grow th rates were determined during 2 series of experiments (Fig. 6) in order to establish minimum ages of $P$. pileus of given sizes. 
Bolinopsis infundibulum (Fig. 7) is a lobate ctenophore. It lived for 7 months in the double kuvette. This device yielded even better results than the planktonkreisel in regard to the maintenance of $B$. infundibulum. No specimens were reared from the egg. In its younger stages, Bolinopsis infundibulum feeds in a way similar to Pleurobrachia pileus namely with its tentacles. In the course of the development of oral

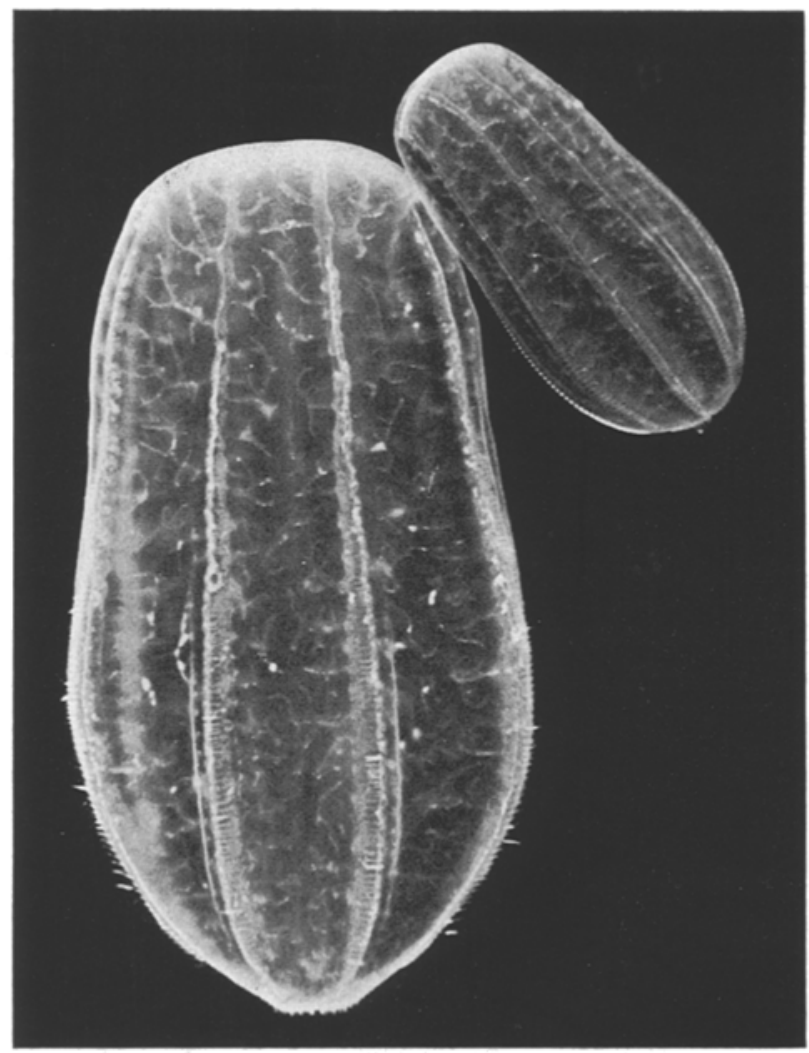

Fig. 9: Beroe cucumis (about 45 and $20 \mathrm{~mm}$ long). Anastomoses of the pleuroclads are an important taxonomic criterion and form a distinct pattern between comb rows

lobes, $B$. infundibulum (about 2-3 $\mathrm{mm}$ long) ceases to use its tentacles. The ctenophore swims mouth forward through the water selecting its prey. As $B$. infundibulum does not rely on mobile prey only, eggs and passive drifters such as some larval forms, are part of the diet of this lobate ctenophore as well as of other comparable species (Nelson 1923, 1925, Nagabushanam 1959, Kamshilow 1960b, Bishop 1968, 1969). In regard to its body structure Bolinopsis infundibulum is one of the most delicate plankton animals. In the phytoplanktonkreisel experiments the wave maker destroyed many more specimens of $B$. infundibulum than of any other species examined. However, $B$. infundibulum is capable of regenerating damaged body portions. Thus oral lobes were completely regenerated within one week's time. 
The growth rate (body size) of Bolinopsis infundibulum (Fig. 8) exceeds that of Pleurobracbia pileus (Fig. 6). The variations in growth rate within a given population equals that in $P$. pileus.

The difficulty of obtaining living food organisms limited the time of maintenance of Beroe cucumis (Fig. 9) in the planktonkreisel to 35 days. The double kuvette also seems to be useful for culturing $B$. cucumis.

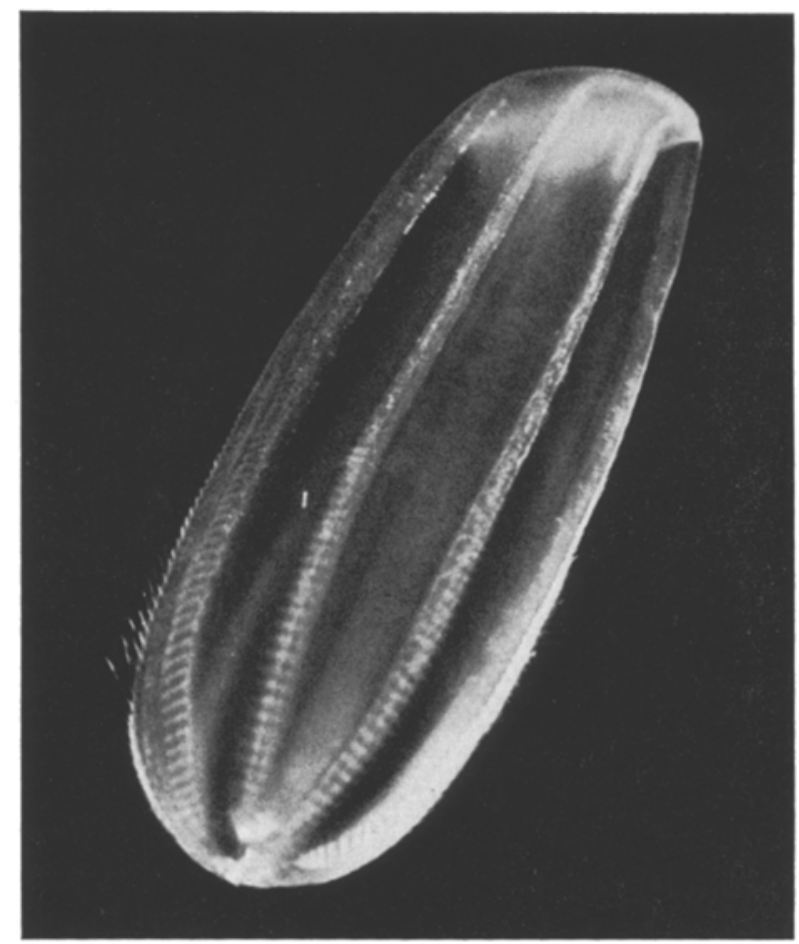

Fig. 10: Beroe gracilis (20 mm long). The anastomoses, found in Beroe cucumis (Fig. 9) are lacking; the body is slender, the motion faster than in $B$. cucumis of the same size

Kamshilow $(1955,1959,1960 \mathrm{a}, \mathrm{b})$ studied Beroe cucumis in detail and found that it feeds exclusively on other ctenophores. This finding is supported by our investigation; it was possible to show that $B$. cucumis significantly prefers Bolinopsis infundibulum to Pleurobrachia pileus as food. The latter is either not eaten at all, or regurgitated sooner or later, or digested much more slowly than $B$. infundibulum. For example, $B$. cucumis of $43 \mathrm{~mm}$ length practically digested 4 specimens of $B$. infundibulum of $25 \mathrm{~mm}$ length within $2 \mathrm{~h}$; the same individual needed $7 \mathrm{~h}$ to digest a $P$. pileus of $12 \mathrm{~mm}$ diameter to the same extent. All attempts to feed $B$. cucumis entirely on $P$. pileus failed; the $B$. cucumis decreased in size and died.

When searching for prey, Beroe cucumis is an active swimmer, moving mouthforward through the water. When its anterior part touches a $B$. infundibulum its 
mouth opens wide, while the body bends sharply. The prey is then rapidly sucked into the pharynx.

According to Kamshilow (1959) Beroe increases in length from 35 to $49 \mathrm{~mm}$ within 1 month when fed 1 Bolinopsis infundibulum (10 to $25 \mathrm{~mm}$ long) per day. In an own experiment each $B$. cucumis received $2 B$. infundibulum per day; within 10 days the $B$. cucumis grew from $3-5 \mathrm{~mm}$ to $22-43 \mathrm{~mm}$ length respectively. The size

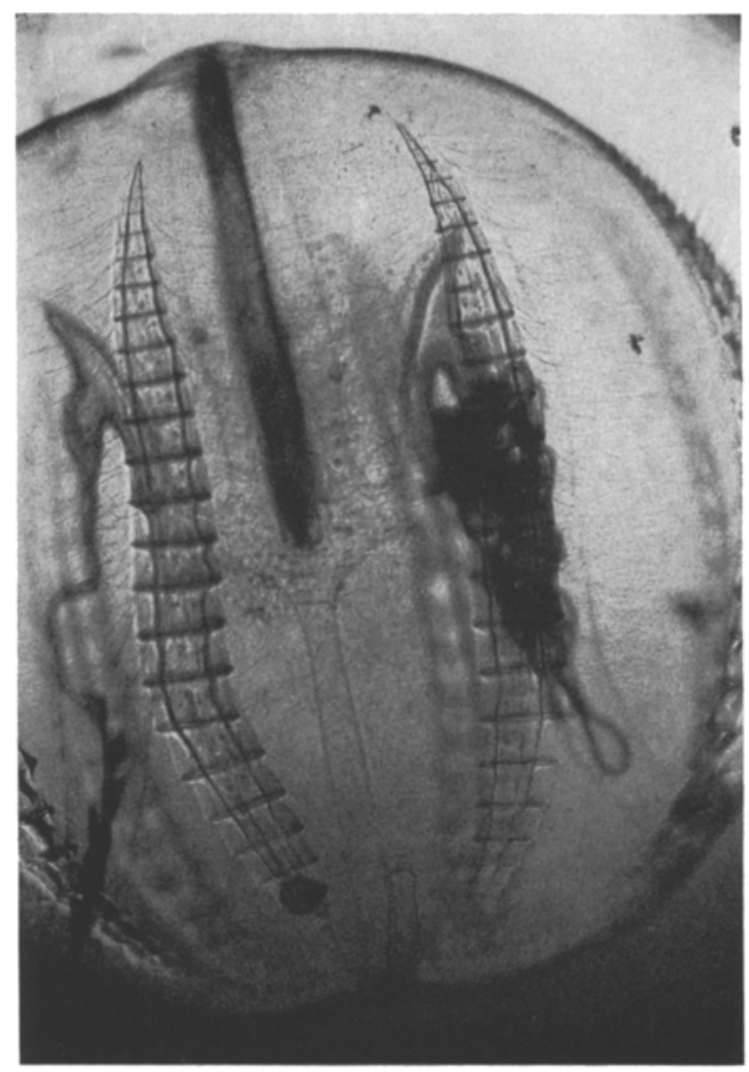

Fig. 11: Beroe gracilis, a young specimen clinging to the cilia of Pleurobracbia pileus. At the lower end of the right comb row (near the polar field) a $B$. gracilis of $0.5 \mathrm{~mm}$ length is visible on the adult ctenophore of $10 \mathrm{~mm}$ diameter

of the $B$. infundibulum offered increased within this period from 5 to $25 \mathrm{~mm}$ length; in other words with increasing length $B$. cucumis received progressively larger prey.

Beroe gracilis (Fig. 10) is the more common one of the Beroe species of the southern North Sea (KüNNE 1939). This ctenophore could be cultivated over 2 generations. The longest maintenance period for one specimen was 6 months. The planktonkreisel and the double kuvette have been successfully used for maintenance of this species.

Beroe gracilis fed entirely on Pleurobracbia pileus in all experiments; it starved 
to death in the presence of Bolinopsis infundibulum. The young stages of B. gracilis do not only rely on young $P$. pileus of appropriate sizes for food but also cling to cilia and tentacles of adult specimens (Fig. 11) in a kind of temporary ectoparasitism. While young $B$. gracilis attach themselves with the help of their scythe-shaped macrocilia to beating cilia of their prey, adults sometimes maintain a hold on bigger $P$. pileus by widening their mouth to form a sucking disc.

Beroe gracilis often produces eggs soon after being fed. Usually a specimen of about $17 \mathrm{~mm}$ in length lays eggs within the first $48 \mathrm{~h}$ after feeding, provided that

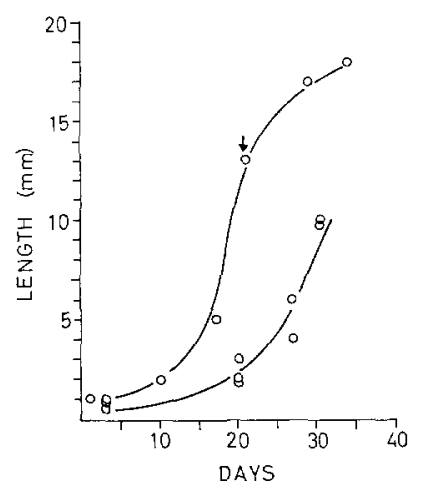

Fig. 12: Beroe gracilis. Increase in body length; the upper curve was obtained from 1, the lower from 3 specimens. The arrow marks the time of the first egg production $\left(15^{0}-18^{\circ} \mathrm{C}\right)$

previously no abnormal conditions (e. g. temperature) or starvation periods have occurred, and that the amount of food given exceeds average requirements. At $15^{\circ} \mathrm{C}$ hatching takes place 24 to $48 \mathrm{~h}$ after fertilisation. Increase in body length is lower in $B$. gracilis (Fig. 12) than in B. cucumis. Sexual maturity is reached at a length of 10 to $15 \mathrm{~mm}$; Thereafter, growth rate decreases and increasing proportions of the food consumed are converted into sexual products. At 25 to $30 \mathrm{~mm}$ there is no further increase in body length; obviously all food assimilated is expended for biologically useful energy and sexual products.

\section{DISCUSSION}

It has been possible by employing modern cultivation equipment, especially planktonkreisel, phytoplanktonkreisel and double kuvette, to gain new insights into the life cycle, feeding habits and other important ecological aspects of 4 species of ctenophores. These species constitute important members of the planktonic eco-system of the southern North Sea. While it was possible to rear Pleurobracbia pileus and Beroe gracilis from egg to egg, mortality was high, especially in newly hatched specimens. Average mortality was roughly $99 \%$. I have not yet attempted to breed Bolinopsis infundibulum and Beroe cucumis. Even though young ctenophores are frequently referred to as larvae, this term can properly be used for young Bolinopsis 
infundibulum only. The criterion for the existence of larvae proper is the presence of typical larval organs which later disappear or become reduced in the adult. The larval organs of $B$. infundibulum are the tentacles.

Our cultivation experiments revealed clearly that both Beroe species of the southern North Sea are predators, highly specialised in regard to their prey. It was possible on the basis of numerous feeding experiments (GREVE 1969) to establish that Beroe gracilis from the southern North Sea feed exclusively on Pleurobrachia pileus Beroe cucumis feed almost exclusively on Bolinopsis infundibulum. These special prey predator relations represent 2 important ecological feedback systems which significantly affect population dynamics in the southern North Sea. Within each feed back system quantitative predator-prey relations are direct; both members of the system affect each other immediately (primary effects). Abundance maxima of prey species in late spring are followed by abundance maxima of predator species in early summer. While these primary quantitative dynamics are obvious, the resulting variations in abundance of the prey species lead to a variety of secondary, tertiary, etc., effects on other members of the ecosystem which are far more difficult and complex to assess, their complexity being a direct function of the number of interspecific relationships of the prey species.

Beroe gracilis has often been confused with B. cucumis (Greve 1969). In view of the above mentioned ecological relationships and nutritional specialisations, we must expect that Beroe gracilis occurs in all areas in which Pleurobrachia pileus is abundant. From the photographs, presented in this paper (Figs 9 and 10), B. gracilis can easily be identified (no anastomoses between pleuroclads). Unfortunately, LILEY (1958) has redescribed $B$. gracilis from KüNNE's (1939) German paper, using his characteristics of $B$. cucumis.

\section{SUMMARY}

1. The development of new cultivation devices, the double kuvette and the phytoplanktonkreisel, made it possible to culture the 4 species of ctenophores occurring in the southern North Sea: Pleurobrachia pileus, Bolinopsis infundibulum, Beroe cucumis and Beroe gracilis. These ctenophores are holoplanktonic organisms of great ecological importance in local marine food chains.

2. The double kuvette, an improved version of the planktonkreisel permits the control of growth and feeding rate without disturbing the test organisms.

3. The phytoplanktonkreisel permits experiments close to habitat conditions with high seston densities and wave action.

4. Beroe gracilis and Pleurobrachia pileus could be reared from egg to egg; the other 2 species could be maintained over several weeks.

5. Data are given on the nutrition of all 4 species as well as on their growth rates, development and behavior.

6. Beroe gracilis feed exclusively on Pleurobrachia pileus; Beroe cucumis feed mainly on Bolinopsis infundibulum. 
7. The young stages only of Bolinopsis infundibulum have true larval organs (tentacles) and may be called larvae.

8. Some ecological implications of the findings are discussed.

Acknowledgements. I wish to express my thanks to Professor O. KINNE, who made these investigations possible in the Biologische Anstalt Helgoland and helped me with the preparation of this paper. Furthermore, I am indebted to the craftsmen of that institution, especially to Mr. P. Hofmann, for their help in building the cultivation devices.

These studies represent a part of a dissertation (Mathematisch-Naturwissenschaftliche Fakultät der Universität Kiel) on the ecology of Pleurobrachia pileus.

\section{LITERATURE CITED}

Brshop, J. W., 1968. Comparative study of feeding by the ctenophores Bolinopsis and Pleurobrachia. In: Abstracts of papers submitted for the 31st Annual Meeting of the American Society of Limnology and Oceanography, Madison, Wisc. 17 - 21. 6. 1968.

- 1969. A comparative study of feeding rates of tentaculate ctenophores. Ecology 49, 996-997.

FRASER, H. J., 1962. The role of ctenophores and salps in zooplankton production and standing crop. Rapp. P.-v. Réun. Cons. perm. int. Explor. Mer 153, 121-123.

Greve, W., 1968. The "planktonkreisel" a new device for culturing zooplankton. Mar. Biol. 1, 201-203.

- 1969. Zur Ókologie der Ctenophore Pleurobrachia pileus FABr. Math.-nat. Diss., Kiel, 138 pp.

Hauenschild, C., 1968. Invertebraten. In: Methoden der meeresbiologischen Forschung. Hrsg. von C. Schlieper. G. Fischer, Jena, 192-209.

Kamshilow, M. M., 1955. The nutrition of a ctenophore Beroe cucumis Fabr. Dokl. Akad. Nank. SSSR 102, 399-405.

- 1959. Interrelationships between organisms and the part they play in evolution. (Tr. by Z. Kabata.) Zb. obshch. Biol. 20 (5), 370-378.

- 1960a. Feeding of a ctenophore Beroe cucumis. Dokl. Akad. Nauk.SSSR 130 (5), 1138-1140.

- 1960b. Biology of ctenophores off Murman. In: Council Meeting (C. M.). International Council for the Exploration of the Sea (I.C.E.S.). 157.

KüNNE, C., 1939. Die Beroe (ctenophora) der südlichen Nordsee, Beroe gracilis, n. sp. Zool. Anz, 127, 172-174.

LILEY, R., 1958. Ctenophora. Fich. Ident. Zooplancton 82.

Nagabushanam, A. K., 1959. Feeding of a ctenophore Bolinopsis infundibulum O. F. MüLlER. Nature, Lond. 184, 829.

Nelson, T. C., 1923. On the occurrence and food habits of certain ctenophores. Anat. Rec. 26, 381.

- 1925. Occurrence and feeding habits of ctenophores in New Jersey coastal waters. Biol. Bull. mar. biol. Lab., Woods Hole 48, 92-111.

Wenzel, B., 1958. Glastiere des Meeres. Rippenquallen. Ziemsen, Wittenberg, 47 Pp. (Neue Brehm-Bücherei. Heft 213.)

Author's address: Dr. W. Greve

Biologische Anstalt Helgoland

Meeresstation

2192 Helgoland

Germany (FRG) 